\title{
Sirozlu çocuklarda kalp fonksiyonlarının doku Doppler görüntüleme ile değerlendirilmesi
}

\author{
Evaluation of cardiac functions in cirrhotic children using tissue Doppler imaging
}

\author{
Elif ÇELIK¹, Cemşit KARAKURT², Serkan Fazlı ÇELIK², Ayşe SELIMOĞLU³, Fatma IIlknur VAROL³ \\ 'Özel Magnet Hastanesi, Çocuk Sağlığı ve Hastalıkları Bölümü, Kayseri \\ İnönü Üniversitesi Tıp Fakültesi, Çocuk Sağlığı ve Hastalıkları Anabilim Dalı, ${ }^{2}$ Çocuk Kardiyolojisi Bilim Dalı, ${ }^{3}$ Çocuk Gastroenterolojisi \\ Bilim Dalı, Malatya
}

\begin{abstract}
Giriş ve Amaç: Sirotik kardiyomiyopati (CCM) siroz varlığında oluşan kardiyak disfonksiyon olarak tanımlanmaktadır. Pediatrik yaş grubunda sirotik kardiyomiyopati ile ilgili yapılmış çok az sayıda çalışma vardır. Bu çalışmada sirozlu çocuklarda kardiyak fonksiyonlar ile pulmoner komplikasyonları tespit etmek amaçlandı. Gereç ve Yöntem: Bu çalışmada Inönü Üniversitesi Tıp Fakültesi Çocuk Gastroenteroloji Bölümü'nde, Ekim 2011-Aralık 2013 tarihleri arasında retrospektif olarak iki yıllık süreçte izlenen 52 sirozlu çocuk hasta ile yaş ve cinsiyetleri benzer 30 sağlıklı çocuk konvansiyonel, renkli Doppler ve doku Doppler ekokardiyorafik görüntüleme yöntemleriyle değerlendirildi. Bulgular: Çalışmaya

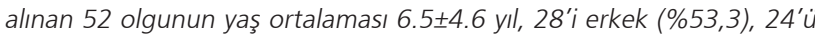
kız $(\% 47,7)$ idi. Kontrol grubunun yaşlarının ortalaması $6.88 \pm 3.04$ yıl, $16^{\prime}$ 's erkek $(\% 53,3), 14^{\prime} u ̈$ kIz $(\% 46,6)$ olmak üzere toplam 30 idi. Hastaların M-mod değerlendirmelerinde sol ventrikül arka duvarı kontrol grubundan daha kalındı (5.9 $\pm 1.7 \mathrm{~mm}$ ve $5.1 \pm 1.8 \mathrm{~mm}, \mathrm{p}: 0.03)$. Renkli Dopplerle mitral kapaktan ölçülen E/A oranı hasta grubunda anlamlı derecede düşüktü $(1.46 \pm 0.43$ ve $1.61 \pm 0.46, p$ : 0.01). Hasta grubu daha uzun izovolümik relaksasyon süresine $(48.5 \pm 12.5 \mathrm{~ms}$ ve $42.6 \pm 11.64 \mathrm{~ms}$,

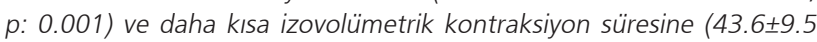
ms ve $48.6 \pm 11.6$ ms, p: 0.001) sahipti. Hasta grubunda sol ventrikülün miyokard performans indeksi anlamlı olarak yüksekti $(0.57 \pm 0.13$ ve $0.50 \pm 0.67, p: 0.02$ ). Hastaların 8 tanesine (\%15) hepatopulmoner sendrom tanisı kondu. Hepatopulmoner sendromlu hastaların ekokardiyografik değerlendirilmelerinde, hepatopulmoner sendromu olmayan hasta grubuna göre interventriküler septum diastolik kalınlığı $(6,9 \pm 1.2$

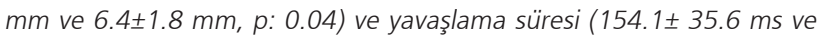
$140.4 \pm 39.8$ ms, p: 0.03) daha fazla idi. Sonuç: Sirotik çocuklarda başta diyastolik disfonksiyon olmak üzere kardiyak disfonksiyon vardır. hepatopulmoner sendromlu grupta bu etkilenme daha fazladır. Çalışmamız doku Doppler ekokardiyografinin, hastalık progresyonunun saptanması ve izlenmesi için yararlı bir yöntem olduğunu göstermektedir.
\end{abstract}

Anahtar kelimeler: Karaciğer sirozu, kardiyomiyopati, doku Doppler görüntüleme, çocuk

\section{GíRis}

Sirozun kardiyovasküler muhtemel sonuçları azalan sistemik vasküler direnç, artmış kardiyak output ve anormal miyokard kontraktilitesi olarak özetlenebilir. Siroza bağlı
Background and Aims: Cirrhotic cardiomyopathy is defined as cardiac dysfunction in the presence of cirrhosis. Several studies have been conducted on cirrhotic cardiomyopathy in cirrhotic children. The aim of this study was to investigate cardiac functions and pulmonary complications in children with cirrhosis. Materials and Methods: This study included 52 cirrhotic pediatric patients who were followed up for 2 years from October 2011 to December 2013 at Inönü University, Faculty of Medicine, Department of Pediatric Gastroenterology. In addition, 30 healthy children of similar age and sex were recruited and assessed using conventional echocardiography, color Doppler echocardiography, and tissue Doppler echocardiography. Results: Mean age of the 52 patients in the study group was $6.5 \pm 4.6$ years; 28 patients were males (53.3\%), and 24 were females (47.7\%). The mean age of the control group children was $6.88 \pm 3.04$ years; 16 were males (53.3\%), and 14 were females (46.6\%). M-mode echocardiographic evaluations of the patients showed increased left ventricular posterior wall thickness compared with that in control children (5.9 \pm 1.7 and $5.1 \pm 1.8 \mathrm{~mm}, p=0.03$ ). The mean E/A ratio measured using colored dorsal mitral valve was significantly lower in the patient group than that in the control group (1.46 \pm 0.43 and $1.61 \pm 0.46, p=0.01)$. The patient group had longer isovolumic relaxation time $(48.5 \pm 12.5$ and $42.6 \pm 11.64 \mathrm{~ms}, p=0.001)$ and shorter isovolumetric contraction time $(43.6 \pm 9.5$ and $48.6 \pm 11.6$ $m s, p=0.001)$ than those in the control group. The myocardial performance index of left ventricle was significantly higher in the patient group $(0.57 \pm 0.13$ and $0.50 \pm 0.67, p=0.02)$ than that in the control group. Eight patients (15\%) were diagnosed with hepatopulmonary syndrome. Echocardiographic evaluations of patients with hepatopulmonary syndrome showed that the interventricular septum diastolic thickness (6.9 \pm 1.2 and $6.4 \pm 1.8 \mathrm{~mm}, p=0.04)$ and the deceleration time (154.1 \pm 35.6 and $140.4 \pm 39.8 \mathrm{~ms}, p=0.03$ ) were greater than those in the non- hepatopulmonary syndrome patient group. Conclusion: Cirrhotic children have cardiac dysfunction, especially diastolic dysfunction. This effect is more pronounced in patients with hepatopulmonary syndrome. Tissue Doppler echocardiography provides a quantifiable indicator that is useful for the detection and monitoring of disease progression.

Key words: Liver cirrhosis, cardiomyopathy, tissue Doppler imaging, child

miyokardiyal disfonksiyonun yavaş ilerleme ile sonuçlanan fonksiyonel ve yapısal miyokardial değişikliklerine sirotik kardiyomiyopati (CCM) denmektedir (1). Tanı kriterleri: 
Sistolik disfonksiyon (egzersizle, volüm artışı veya farmakolojik uyaranlar ile ortaya çıkan) ve dinlenme ejeksiyon fraksiyonu [(EF) <\% 55], diyastolik disfonksiyon (E/A ora$\mathrm{n} ı<1.0$, ) uzamış yavaşlama süresi (DT) > 200 ms, uzamış izovolumetrik gevşeme süresi $>80 \mathrm{~ms}$ ) ve diğer destekleyici kriterler [elektrofizyolojik anomaliler, anormal kronotropik cevap, uzamış Q-T aralığı, genişlemiş sol atriyum (LA), artmış miyokard kütlesi, artmış beyin tipi natriüretik peptit (BNP) ve proBNP ve troponin I düzeyleri] içerir (2). Tanı koymak için yukarıdaki kriterlerin hepsi gerekli değildir (3). Hepatik hastalığa bağlı bu kardiyak disfonksiyon henüz tam olarak sınıflandırılmamış olup mekanizması tam olarak anlaşılmamıştır (4). Bu kalp disfonksiyonu, hastaların prognozunu ve transjugüler interhepatik portosistemik şant, karaciğer transplantasyonu gibi cerrahi işlemler sırasında ve sonrasında hastalık seyrini daha da kötüleştirmektedir (5).

Hepatopulmoner sendrom (HPS), bozulmuş oksijenasyon ve intrapulmoner vasküler anormaliklerle karakterize klinik bir sendromdur. Karaciğer hastalığına HPS'un eşlik etmesi kötü prognostik göstergedir. Bu yüzden HPS'li hastaların en hızlı şekilde tanınmaları pre-post operatif dönemde karşılaşılacak sorunlar açısından çok önemlidir.

Bu çalışmada amaç; karaciğer transplantasyonu adayı hastalarda sol ventrikül fonksiyonlarını ve pulmoner komplikasyonlarını doku Doppler eko ile değerlendirerek pediyatrik sirozlu hasta grubunda CCM varlığını ve HPS sıklığını saptamaktır.

\section{GEREÇ ve YÖNTEM}

Araştırmaya İnönü Üniversitesi Tıp Fakültesi Çocuk Gastroenteroloji Bölümü'nde, Ekim 2011-Aralık 2013 tarihleri arasında iki yıllık süreçte izlenen yaşları 0-18 yaş arasında (ortalaması 6.5 \pm 4.6 yıl) değişen 28 'i erkek $(\% 53,3), 52$ sirozlu çocuk hasta ve kontrol grubu olarak da herhangi bir hastalığı olmayan cinsiyet ve yaş aralığı benzer, çocuk kardiyoloji polikliniğine üfürüm nedeniyle başvurmuş 30 sağlıklı çocuk alındı. Siroz ve komplikasyonları biyokimyasal, serolojik, histopatolojik, ultrasonografik ve endoskopik araştırmalarla tespit edildi. Hastalar yaş ve cinsiyet dağılımı, başvuru yakınmaları, vücut kitle indeksleri, fizik inceleme bulguları, tam kan sayımı, kan biyokimya değerleri, siroza eşlik eden diğer hastalıklar açısından değerlendirildi. Kontrol ve hasta grubunda tüm olgulara $\mathrm{O}_{2}$ satürasyonu, arteryel tansiyon, ekokardiyografi işlemi yapıldı. Hasta grubunda pulmoner arteryovenöz şantları değerlendirmek amacıyla ekokardiyografi sırasında kontrast eko (\%1.5 saline ile) işlemi yapııdı. Çalışmaya katılan tüm gruplardan bilgilendirilmiş onam formu alındı. Çalışma, İnönü Üniversitesi Tıp Fakültesi Etik Komitesi tarafından onaylanmıştır.

\section{Ekokardiyografi}

Ekokardiyografi işlemi, tüm olgulara sol yan pozisyonda yaşa göre uygun problar kullanılarak General Electric (GE, Vivid-5) marka cihaz ile Amerikan Ekokardiyografi Derneği'nin (6) önerilerine uygun olarak uzman bir pediatrik kardiyolog tarafından yapıldı .

Ekokardiyografik çalışma M mod, iki boyutlu, atımlı (PW) ve devamlı (CW) dalga, renkli ve doku Dopplerden (TDI) oluşmaktaydı. Kısalma (FS) ve ejeksiyon fraksiyonları (EF) hesaplandı. Doku Doppler için tüm aralık ölçümleri bir kardiyak döngü içinde gerçekleştirildi. TDI, dört odacık apikal görünümünden elde edildi. Her doku için üç farklı ölçüm ile Doppler indeksi yapıldı ve ortalamaları alındı. Hız indeksleri, örnek hacimler mitral annulusların lateral yanlarından ölçüldü. Zirve sistolik ve erken ve geç diyastolik hızlar ( $E^{\prime}$ ve $A^{\prime}$ ) ölçülüp bu noktalarda $E^{\prime} / A^{\prime}$ oranı hesaplandı. İzovolümetrik gevşeme zamanı (IVRT) ve izovolümetrik kontraksiyon zamanı (IVCT) sol ventrikül (LV) yan duvarları için ölçülmüştür. Ayrıca global miyokard performans indeksinin hesaplanması (MPI indeksi) $a^{\prime}-b^{\prime} / b^{\prime}$ formülü kullanılarak gerçekleştirildi. Kontrast ekokardiyografi işleminde, intravenöz kontrast maddenin (\%1.5 saline) enjeksiyonundan sonra kalbin 3-6 atım sonrasında sol kalpte görülüp görülmemesine göre değerlendirildi.

\section{İstatistiksel Analiz}

Parametrik niceliksel veriler ortalama \pm standart sapma olarak sunuldu. Parametrik olmayan niceliksel veriler ortanca olarak ifade edildi, Kruskall-Wallis ve Mann-Whitney medyanların karşılaştıııması için kullanıldı. Nicel değişkenler arasında korelasyonu saptamak için Pearson korelasyon testi (parametrik veriler için) ya da Spearmen korelasyon testi (nonparametrik veriler için) kullanıldı. Nitel veriler frekans olarak ifade edildi ve yüzde olarak verildi. P değerinin 0.05 'in altında olması anlamlı olarak kabul edildi. Veri yönetimi ve analizi için SPSS 15.0 (SPSS Inc., Chicago, IL, ABD) kullanıldı.

\section{BULGULAR}

Hastaların ortalama yaşları $6.5 \pm 4.6 y ı l$, kontrol grubunun $6.88 \pm 3.04$ yıl idi. Çalışma grubunda 28 erkek ve 24 kız; kontrol grubunda ise 17 erkek $13 \mathrm{kız}$ vardı. Olguların ve kontrollerin yaş ve cinsiyetleri istatiksel olarak benzerdi. Hasta grubunun temel özellikleri Tablo 1'de gösterilmiştir.

M mod değerlendirilmesinde sol ventrikül ejeksiyon fraksiyonu (LVEF) ve kısalma franksiyonu değerleri arasında hasta ve kontrol grubu arasında anlamlı farkllık saptanmadı (p: 0,87 ve 0,78). LV arka duvar kalınlıklarının (LPWD) hasta grubunda kontrol grubuna göre anlamlı derecede 
Tablo 1. Hasta grubunun demografik özellikleri

\begin{tabular}{|c|c|c|}
\hline & Hasta & Oran (\%) \\
\hline \multicolumn{3}{|l|}{ Cinsiyet } \\
\hline Erkek & 28 & 53 \\
\hline $\mathrm{K} ı \mathrm{z}$ & 24 & 47 \\
\hline Yaş (mean $\pm S D)$ & $6.5 \pm 4.6$ & \\
\hline \multicolumn{3}{|l|}{ Altta yatan karaciğer patolojisi } \\
\hline Kronik hepatit & 12 & 23 \\
\hline Ekstrahepatik biliyer atrezi & 6 & 11 \\
\hline Otoimmün hepatit & 8 & 15 \\
\hline Wilson hastalığı & 3 & 5 \\
\hline Alfa 1 antitiripsin eksikliği & 1 & 2 \\
\hline Kriptojenik siroz & 22 & 42 \\
\hline Kontrast eko geçiş & 8 & 15 \\
\hline
\end{tabular}

Tablo 2. Hasta ve kontrol grubunun ekokardiyografik bulguları (M-mod ve renkli Doppler)

\begin{tabular}{|c|c|c|c|}
\hline & $\begin{array}{l}\text { Hasta } \\
\text { N: } 52\end{array}$ & $\begin{array}{c}\text { Kontrol } \\
\text { N: } \mathbf{3 0}\end{array}$ & $\mathbf{P}$ \\
\hline Cinsiyet (E: Erkek, K: Kız) & $28 \mathrm{E} / 24 \mathrm{~K}$ & $17 E / 13 K$ & 0,60 \\
\hline Yaş (mean $\pm \mathrm{SD})$ & $6.5 \pm 4.6$ & $6.8 \pm 4.9$ & 0,75 \\
\hline $\mathrm{EF}(\%)$ & $70,6(7,4)$ & $72,1(9,3)$ & 0,87 \\
\hline FS (\%) & $39,8(6,5)$ & $41,2(8,6)$ & 0,78 \\
\hline IVSd (mm) & $6,3(1.2)$ & $6.8(1.8)$ & 0,13 \\
\hline LVDs (mm) & $19,8(2,3)$ & $20,2(2,6)$ & 0,92 \\
\hline $\operatorname{LVDd}(\mathrm{mm})$ & $27(4.1)$ & $25(4.6)$ & 0,35 \\
\hline LPWD (mm) & $5,9(1,7)$ & $5,1(1,8)$ & 0,03 * \\
\hline$E(\mathrm{~m} / \mathrm{s})$ & $0,97(0,14)$ & $0,98(0,3)$ & 0,16 \\
\hline$A(m / s)$ & $0,66(0,13)$ & $0,59(0,12)$ & 0,58 \\
\hline$E / A$ & $1,46(0,43)$ & $1,61(0,46)$ & 0,01 * \\
\hline DT (ms) & $141,5(30,6)$ & $135,4(34,8)$ & 0,44 \\
\hline
\end{tabular}

EF: Ejeksiyon fraksiyonu, FS: KIsalma fraksiyonu, IVSd: Interventriküler septum kalınlığı, LVDs: Sol ventrikül arka duvarı sistol sonu kalınlığı, LVDd: Sol ventrikül diastol sonu kalınlığı, LPWD: Sol ventrikül arka duvar kalınlığı, E: E dalga velositesi, A: A dalga velositesi E/A: E/A oranı, DT: Yavaşlama süresi ${ }^{*} \mathrm{P}<0,05$

artmış olduğu saptandı (p:0,03). Ayrıca E/A oranı istatiksel olarak anlamlı derecede düşük idi (Tablo 2). TDI parametreleri değerlendirildiğinde hastaların izovolümetrik gevşeme zamanı (IVRT) değerlerinde belirgin artış, izovolümetrik kontraksiyon zamanı (IVCT) değerlerinde ise anlamlı azalma saptandı. Hasta grubunda miyokard performans indeksi (MPI) kontrol olgularından daha belirgin olarak yüksekti (Tablo 3).
Tablo 3. Hasta ve kontrol grubunun doku Doppler eko bulguları

\begin{tabular}{|l|c|c|c|}
\hline & $\begin{array}{c}\text { Hasta } \\
\text { N: } \mathbf{5 2}\end{array}$ & $\begin{array}{c}\text { Kontrol } \\
\mathbf{N}: \mathbf{3 0}\end{array}$ & $\mathbf{P}$ \\
\hline $\mathrm{E}^{\prime}(\mathrm{m} / \mathrm{s})$ & $0,16(0,03)$ & $0,18(0,03)$ & 0,26 \\
\hline $\mathrm{A}^{\prime}(\mathrm{m} / \mathrm{s})$ & $0,081(0,01)$ & $0,76(0,01)$ & 0,34 \\
\hline$E^{\prime} / A^{\prime}$ & $1,97(0,61)$ & $1,85(0,54)$ & 0,40 \\
\hline$E / E^{\prime}$ & $6,3 \pm 1,1$ & $6,1 \pm 0,9$ & 0,54 \\
\hline IVRT (ms) & $48.5(12.5)$ & $42.6(11.6)$ & $\mathbf{0 , 0 0 1 *}$ \\
\hline IVCT (ms) & $43.6(9.5)$ & $48.6(11.6)$ & $\mathbf{0 , 0 0 1}$ \\
\hline MPI indeks & $0,57(0,13)$ & $0,50(0,67)$ & $\mathbf{0 , 0 2}$ \\
\hline
\end{tabular}

É ve Á: Erken ve geç diyastolik miyokardial velositeler, IVRT: İzovolümetrik gevşeme zamanı, IVCT: İzovolümetrik kontraksiyon zamanı, MPI: Miyokardial performans indeksi * $P<0,05$

HPS saptanan hastalar da $\mathrm{O}_{2}$ saturasyonu (\%91.5), HPS olmayan hastalara $(\% 95.2, \mathrm{p}: 0,03)$ ve kontrol $(\% 97.5$, p:0,01) grubuna göre anlamlı derecede düşüktü. Bu hastalarda M-mod değerlendirmelerinde LPWD değerleri kontrol grubuna göre anlamlı yüksek olsa da HPS olmayan hastalara göre anlamlı farklılık saptanmadı. TDI sonuçlarından ise IVRT ve MPI indeksleri kontrol grubuna göre anlamlı yüksek olsa da HPS olmayan hastalara göre anlamlı farklılık saptanmadı (Tablo 4).

\section{TARTISৃIMA}

Karaciğer hastalı̆̆ı stabil olan çoğu hastada rutin ekokardiografik değerlendirmelerde miyokard bozukluğu saptanmaz. Fakat, karaciğer hastalığının ilerlemesiyle veya fizyolojik/farmakolojik zorlamalarla kalp yetmezliği belirginleşmeye başlar (7). Son yıllarda özellikle sirozlu hastalarda bazı kardiyak anormalliklerin varlığı çeşitli çalışmalarla dikkatleri çekmeye başlamıştır.

Bu çalışmada, sirozlu 52 çocuğun kardiyak fonksiyonları hem konvansiyonel ekokardiyografi hem de TDI ile değerlendirildi. Bizim çalışmamızda da sirozlu hastalarda önemli ölçüde artmış LPWD değerleri saptandı. Benzer sonuç Kazankov ve ark.larının 2010 yılında 42 sirozlu hasta ile yaptıkları doku doppler çalışmasında da saptanmışırı (16). Hastalarımızın kısalma fraksiyonu (FS) ve EF ile değerlendirilen sistolik fonksiyonları normal sınırlardaydı. Tugcin ve ark.nın kronik hepatitli 63 pediyatrik hastada yaptıkları doku Doppler çalışmasında sol ventrikül fonksiyonlarının son döneme kadar korunduğu belirtilmişdir (8).

Hasta grubunda TDI ile ölçülen LV sistolik zirve hızı, siroza eşlik eden kardiyak hiperdinamiden dolayı azalmamış 
Tablo 4. Hasta grubunda HPS olan ve olmayanların demografik ve ekokardiyografik bulguları

(M-mod ve renkli Doppler)

\begin{tabular}{|c|c|c|c|}
\hline & $\begin{array}{c}\text { HPS } \\
\text { Olanlar }\end{array}$ & $\begin{array}{c}\text { HPS } \\
\text { Olmayanlar }\end{array}$ & $\mathbf{P}$ \\
\hline & $N: 8$ & $\mathrm{~N}: 44$ & \\
\hline Yaş (mean $\pm S D)$ & $6,6 \pm 5,4$ & $6.3 \pm 5.1$ & 0,46 \\
\hline Cinsiyet (E: erkek, K: kız) & $4 \mathrm{E} / 4 \mathrm{~K}$ & $24 \mathrm{E} / 20 \mathrm{~K}$ & 0,88 \\
\hline Satürasyon (\%) & 91.5 & 95.2 & 0,03 * \\
\hline$E^{\prime}(\mathrm{m} / \mathrm{s})$ & $0,18(0,03)$ & $0,19(0,04)$ & 0,36 \\
\hline$A^{\prime}(m / s)$ & $0,94(0,13)$ & $0,86(0,11)$ & 0,44 \\
\hline$E^{\prime} / A^{\prime}$ & $1,88(0,69)$ & $1,88(0,64)$ & 0,49 \\
\hline$E / E^{\prime}$ & $6,6 \pm 1,2$ & $6,8 \pm 0,14$ & 0,64 \\
\hline IVRT (ms) & $50.5(14.5)$ & $52.6(14.6)$ & 0,35 \\
\hline IVCT (ms) & $47.1(9.5)$ & $47.6(11.9)$ & 0,66 \\
\hline MPI indeks & $0,56(0,16)$ & $0,59(0,17)$ & 0,36 \\
\hline $\mathrm{EF}(\%)$ & $69,4(8,4)$ & $73,6(8,8)$ & 0,90 \\
\hline FS (\%) & $34,8(4,5)$ & $35,2(9,6)$ & 0,82 \\
\hline IVSd (mm) & $6,9(1.2)$ & $6,4(1.8)$ & $0,04^{*}$ \\
\hline LVDs (mm) & $20,1(3,4)$ & $19,2(1,2)$ & 0,88 \\
\hline LVDd (mm) & $29(3,8)$ & $28(5.6)$ & 0,45 \\
\hline LPWD (mm) & $5,2(1,4)$ & $5,4(1,9)$ & 0,50 \\
\hline$E(\mathrm{~m} / \mathrm{s})$ & $0,99(0,16)$ & $1,02(0,5)$ & 0,46 \\
\hline$A(m / s)$ & $0,61(0,13)$ & $0,57(0,10)$ & 0,65 \\
\hline$E / A$ & $1,51(0,39)$ & $1,59(0,66)$ & 0,50 \\
\hline DT (ms) & $154,1(35,6)$ & $140,4(39,8)$ & 0,03 * \\
\hline
\end{tabular}

É ve Á: Erken ve geç diyastolik miyokardiyal velositeler, IVRT: İzovolümetrik gevşeme zamanı, IVCT: İovolümetrik kontraksiyon zamanı, MPI: Miyokardial performans indeksi, EF: Ejeksiyon fraksiyonu, FS: Kısalma fraksiyonu, IVSd: Interventriküler septum kalınlığı, LVDs: Sol ventrikül arka duvarı sistol sonu kalınlığı, LVDd: Sol ventrikül diastol sonu kalınlığı LPWD: Sol ventrikül arka duvar kalınlığı, E: E dalga velositesi, A: A dalga velositesi E/A: E/A oranı, DT: Yavaşlama süresi

${ }^{*} \mathrm{P}<0,05$

olabilir. Kontrol grubuyla karşılaştırılı̆̆ında hasta grubunda mitral kapaktan ölçülen E/A oranı anlamlı derecede azalmış ve IVRT anlamlı derecede uzamış idi. Bu parametreler diyastolik disfonksiyon belirteçleri olup Fattouh ve ark. 2016 yılında yaptıkları 53 sirozlu pediyatrik hastadaki doku Doppler çalışmasında E/A anlamlı derecede azalmış ve IVRT anlamlı derecede uzamış olarak saptamışlardır (9). Wong ve ark. 36 sirozlu hastada IVRT değerlerini kontrol grubuna göre anlamlı derecede uzamış olarak saptamışlardır. Aynı çalışma da E/A oranında ise anlamlı farklılık saptamamışlardır (10). Bu hastalarda diyastolik disfonksiyonun altında yatan nedenin, muhtemelen artmışın miyokard duvarındaki kalınlaşma sonucu miyokardi- al hipertrofisi, fibrozis ve subendotelyal ödem ve bunların sonucunda artan sol ventrikül ve atriyumun basınçları olduğunu göstermektedir (7).

Özellikle karaciğer sirozunun eşlik ettiği hiperdinamik durumlarda diyastolik disfonksiyonu değerlendirmede kullanılan TDI ile renkli Doppler indekslerinin birleştirilmesi ile oluşturulan E/E' parametresi ve MPI'nin kullanılması bu hastaların sistolik ve diyastolik kalp fonksiyonunu önemli ölçüde yansıtan bir parametredir (11). E/E' parametresi açısından hasta ve kontrol grubu arasında anlamlı fark saptanmamış olup, hasta grubunda saptanan MPI kontrol grubuna göre anlamlı derecede yüksek bulundu. Bu da hasta grubunda global kardiyak işlev bozukluğunu göstermektedir. Fattouh ve ark. sirozlu pediyatrik hastada ki doku Doppler çalışmasında MPI'ni kontrol grubuna göre anlamlı derece yüksek saptamışlardır (9).

Biz çalışmaya aldığımız hasta grubunda HPS sıklığını \%15 olarak olarak saptadık. Ülkemizde benzer bir çalışma yapılmamış olup, sonuçlarımızı yurt dışından bildirilen az sayıda çalışmayla kıyasladık. Sasaki ve ark. (12) biliyer atrezili çocuklarda prevalansı \%9-20, Barbe ve ark. (13) portal ven trombozu olan çocuklarda \%0.5 olarak bulmuşlardır. Noli ve ark. (14) siroz veya şiddetli pulmoner hipertansiyonu olan 301 çocuğun \% 8'inde HPS saptamışlardır. Önceki her iki çalışmada da bulunan sonuçlar çalışmamızda saptadığımız sonuçlarla paralellik göstermektedir.

Şu ana kadar HPS'li olan ve olmayan çocukları ekokardiografik olarak kıyaslayan bir çalışmaya rastlanmamıştır. Çalışmamızda sirotik çocuk hastalarda interventriküler septum kalınlığı (IVSd) kalınlığının kontrol grubuna göre istatistiksel olarak anlamlı derecede artmış olduğunu belirledik. Bu durumun muhtemel sebebi HPS'li hastaların pulmoner patolojiye bağlı daha fazla kardiyak yüklenmelerinden kaynaklanabilir. Ayrıca, hasta grubunda LV diyastolik disfonksiyonu gösteren yavaşlama süreci (DT) değeri istatistiksel olarak daha uzun idi. TDI parametreleri açısından HPS'li olan ve olmayan hastalar arasında önemli bir fark saptanmadı. Bu HPS'li hasta grubunun sayıca az olmasından kaynaklanıyor olabilir.

Çalışmamızda hastaların uzun süreli takibi ve takip için gerekli veri yokluğu ile hastalarımızın diürezin farklı evrelerinde olması ve bu nedenle intravasküler hacim durumlarındaki farklııklar temel sınırlamalardı.

Sirotik çocuklarda bilinen başka bir kalp rahatsızlı̆ı̆ının olmamasına rağmen sirotik kardiyomiyopatiye bağlı kardiyak disfonksiyon olabilir. Konvansiyonel ekokardiografik değerlerin normal olmasına rağmen hem diyastolik hem de global teşhis için TDI'nın kullanımı CCM'li hastaları saptamak için yardımcı olabilir. 
Özellikle çocuklarda CCM tanısında, daha ileri klinik veya laboratuvar çalışmalara ihtiyaç vardır. Bu çalışmaların daha ileri ekokardiyografik bulgularla ilişkilendirilmesi hastaların tanı ve tedavilerinde faydalı olacaktır.

\section{KAYNAKLAR}

1. Páll A, Czifra A, Vitális Z, et al. Pathophysiological and clinical approach to cirrhotic cardiomyopathy. J Gastrointestin Liver Dis 2014;23:301-10.

2. Møller S, Henriksen JH. Cirrhotic cardiomyopathy J Hepatol 2010;53:179-90.

3. Baik SK, Fouad TR, Lee SS. Cirrhotic cardiomyopathy. Orphanet J Rare Dis 2007;2:15.

4. Naschitz JE, Slobodin G, Lewis RJ, et al. Heart diseases affecting the liver and liver diseases affecting the heart. Am Heart $J$ 2000;140:111-20.

5. Møller S, Henriksen JH, Bendtsen F. Extrahepatic complications to cirrhosis and portal hypertension: Haemodynamic and homeostatic aspects. World J Gastroenterol 2014;20:15499-517.

6. Kazankov K, Holland-Fischer P, Andersen NH, et al. Resting myocardial dysfunction in cirrhosis quantifed by tissue Doppler imaging. Liver Int 2011;31:534-40.

7. Gassanov N, Caglayan E, Semmo N, et al. Cirrhotic cardiomyopathy: A cardiologist's perspective. World J Gastroenterol 2014;20:15492-8.

8. Tugcin BP, Urganci N, Yalim Y, et al. Evaluation of cardiac function by tissue Doppler imaging in children with chronic hepatitis. J Pediatr Gastroenterol Nutr 2006;43:222-7.

9. Fattouh AM, El-Shabrawi MH, Mahmoud EH, et al. Evaluation of cardiac functions of cirrhotic children using serum brain natriuretic peptide and tissue Doppler imaging. Ann Pediatr Card 2016;9:22-8.

10. Wong F, Siu S, Liu P, Blendis LM. Brain natriuretic peptide: Is it a predictor of cardiomyopathy in cirrhosis? Clin Sci 2001;101:621-8.

11. Meric M, Yesildag O, Yuksel S, et al. Tissue doppler myocardial performance index in patients with heart failure and its relationship with haemodynamic parameters. Int J Cardiovasc Imaging 2014;30:1057-64.

12. Sasaki T, Hasegawa T, Kimura T, et al. Development of intrapulmonary arteriovenous shunting in postoperative biliary atresia: evaluation by contrast-enhanced echocardiography. J Pediatr Surg 2000;35:1647-50.

13. Barbe' T, Losay J, Grimon G, et al. Pulmonary arteriovenous shunting in children with liver disease. J Pediatr 1995;126:571-9.

14. Noli K, Solomon M, Golding F, et al.Prevalence of hepatopulmonary syndrome in children. Pediatrics 2008;121:e522-7. 